\title{
Impact of Fishing and Stocking Practices on Coregonid Diversity
}

\author{
Orlane Anneville1", Emilien Lasne1, Jean Guillard1, Reiner Eckmann2, Jason D. Stockwell3, \\ Christian Gillet'1, Daniel L. Yule ${ }^{4}$ \\ ${ }^{1}$ INRA UMR CARRTEL, Thonon-les-Bains, France \\ ${ }^{2}$ Limnological Institute, University of Konstanz, Konstanz, Germany \\ ${ }^{3}$ University of Vermont, Rubenstein Ecosystem Science Laboratory, Burlington, USA \\ ${ }^{4}$ Great Lakes Science Center, U.S. Geological Survey, Ashland, USA \\ Email: ${ }^{*}$ orlane.anneville@thonon.inra.fr
}

Received 28 May 2015; accepted 23 August 2015; published 26 August 2015

Copyright (C) 2015 by authors and Scientific Research Publishing Inc.

This work is licensed under the Creative Commons Attribution International License (CC BY).

http://creativecommons.org/licenses/by/4.0/

(c) (i) Open Access

\section{Abstract}

Fish species diversity can be lost through interacting stressors including habitat loss, stocking and overfishing. Although a multitude of stressors have played a role in the global decline of coregonid (Coregonus spp.) diversity, a number of contemporary studies have identified habitat loss stemming from eutrophication as the primary cause. Unfortunately, reconstructing the role of fishing and stocking practices can be difficult, because these records are incomplete or appear only in hard-to-access historic grey literature. Based on an illustrative set of historic and contemporary studies, we describe how fisheries management practices may have contributed to coregonid diversity loss in European and North American lakes. We provide case studies examining how fishing and stocking may reduce coregonid diversity through demographic decline and introgressive hybridization. In some lakes, fisheries management practices may have led to a loss of coregonid diversity well before issues with habitat degradation manifested. Our review suggests that fish conservation policies could beneficially consider the relative importance of all stressors, including management practices, as potential drivers of diversity loss.

\section{Keywords}

Coregonus, Extinction, Lake, Overfishing, Species Loss

\section{Introduction}

Fluctuation of fish populations is one of the most studied themes in marine and freshwater ecology. In the context of global changes and the increasing human demand for fish protein and oil, it is essential to assess the main stressors impacting fish populations to avoid stock collapses and promote sustainable fisheries. While scientists

\footnotetext{
${ }^{*}$ Corresponding author.
}

How to cite this paper: Anneville, O., Lasne, E., Guillard, J., Eckmann, R., Stockwell, J.D., Gillet, C. and Yule, D.L. (2015) Impact of Fishing and Stocking Practices on Coregonid Diversity. Food and Nutrition Sciences, 6, 1045-1055. 
have debated how natural fish population dynamics are influenced by density dependence, environmental forcing and fishing mortality, fish farming and supplemental stocking have increased to meet growing human demands. Ironically, these practices have been shown to negatively affect wild populations when farmed fish hybridize with wild fish [1]-[3] leading to an overall decline in biodiversity. Consequently, disentangling the impacts of environmental changes, fisheries management, and understanding their interactions has become a major challenge for developing sustainable fishery policies [4]-[8]. Fisheries management is now recognized as a major driver influencing fish biodiversity. For example, coregonid introductions in Norway have strongly impacted native fish populations [9] and massive stocking of Baltic whitefish in Alpine lakes negatively impacted diversity of native whitefish [10]. This issue has been largely addressed [4] [11] with fisheries management and exploitation identified as a prominent threat for fish biodiversity [12] and intra-specific diversity [13]. In addition, a recent study that focused on coregonids showed that eutrophication was the major driver of fish extinctions in several European pre-alpine lakes [14], renewing debate on the relative importance of factors leading to the loss of coregonid diversity.

Coregonids are a large resource with a wide circumpolar distribution. They exhibit high diversity at both large and small geographical scales as they often present various ecotypes with high plasticity [15]-[18]. Adaptive radiation is the most likely mechanism involved in coregonid diversity [19] [20]. As postglacial lake fish, coregonids have evolved in discrete environments having high habitat heterogeneity. Based on a monophyletic lineage, various phenotypes specialized to utilize a wide range of lake habitat, leading to sympatric population divergence (i.e., ecological speciation, [21]). As a result, in a single lake, various morphs or even species may coexist, having specific spawning habitats and dates, gill raker numbers, and other morphological adaptations to utilize benthic or pelagic prey resources [22]-[26].

At present, because of multiple anthropogenic-induced stressors, coregonid diversity is threatened worldwide [14] [27] [28]. Coregonid populations inhabit ecosystems that have suffered various kinds of habitat degradation such as acidification [29] and eutrophication [14] which has led to population declines. While acidification has been shown to reduce fertility on males and females [30], eutrophication impairs egg survival. Coregonids are very sensitive to eutrophication, because their eggs typically incubate on lake-floor with development and hatching requiring an oxygenated water-sediment interface [31]; thus, eutrophication has contributed to the decline of populations in many lakes [32] [33]. In addition to these impacts, eutrophication may relax the mechanisms that maintained ecological niches used by different species, leading to introgressive hybridization [34], and ultimately reduced diversity through speciation reversal [14].

As a largely exploited resource, coregonids may also suffer from fishing pressure and supplemental stocking practices. Unfortunately, historical data on fisheries management actions are often incomplete. Practices such as historic stocking may be poorly traceable andcritical information published in grey literature and from interviews with fisheries and hatcheries managers are not easily accessed by the scientific community. This has led to an under appreciation of the role fishery practices played in the loss of diversity. Although reconstructing how fishery practices may have impacted species diversity can be a daunting challenge, it is important to try if we hope to understand the trend of declining coregonid diversity worldwide.

Here, we offer a narrative review of how fisheries management practices may have led to a decline in coregonid diversity. The objective is to illustrate, with actual case studies, that fisheries management practices may negatively impact coregonid populations, especially in ecosystems impacted by various anthropogenic pressures such as eutrophication (e.g. European alpine lakes) or species invasions (e.g., Laurentian Great Lakes of North America).

To assemble this review, we searched the web of science database using the search strings: 1) lake, 2) fishing or stocking or translocation or over fishing, and 3) coregonus or coregonid, and 4) "species losses" or diversity or extinction. The number of papers that have been published on these topics during the available searched timeframe (1975 to 2014) was 88. Hits were judged for relevance by inspecting the title and abstract. Only 19 papers dealt with the impact of fisheries management on coregonid diversity and more than half were on Great Lakes of North America and Alpine lakes. For those sites, the search was supplemented by grey literature to gather information illustrating the impact of fish management on coregonid diversity.

\section{Historical Practices of Coregonids Fisheries Management in the Northern Hemisphere}

In Europe, fishing for coregonids dates back to the Celts, and there is evidence that fisheries management has 
been practiced since the Middle Ages [35]. Yields greatly increased through the $20^{\text {th }}$ century as the numbers of fishers increased and efficient fishing methods were developed [36]. In response to increasing yields and other anthropogenic stressors, coregonid populations became the subject of study and intense management. By the end of the $19^{\text {th }}$ century, coregonids were introduced into multiple lakes in the European Alps [35] [37] well before documented cases of eutrophication became widespread [14] [31] [34]. By the time, declining oxygen levels associated with eutrophication were discovered to negatively affected egg survival [38], stocking that had been successful in some lakes, was being proposed as a solution to maintain populations in lakes undergoing eutrophication. Thus, for almost a century, stocking was a common practice that operated with little regard to how translocation among lakes might affect diversity [39]. As an example, Switzerland only incorporated genetic considerations into fisheries legislation as recently as 1991 (Federal law of 21 July 1991 on fisheries, Swiss Federal Registrar of Fisheries).

The Laurentian Great Lakes of North America once supported 25 species of coregonids [40]. Of these, lake whitefish (C. clupeaformis) were so important to native people for sustenance that they built their villages near whitefish spawning grounds [41]. By the mid-1800s, commercial fisheries for lake whitefish, cisco (C. artedi), and several deepwater species collectively called deepwater ciscoes (mainly bloater $C$. hoyi and shortjaw cisco C. zenithicus) were fully developed in each lake [42]. Declines in lake whitefish were observed at some ports as early as the 1860s which [42] attributed to overfishing. By the end of the $19^{\text {th }}$ century, cisco dominated the commercial catch [43] with yields of this species averaging 12 million kilograms annually during 1910-1955 [44]. By the 1960s, cisco populations in all lakes, but Lake Superior had collapsed [44] owing to overfishing, habitat destruction, and invasive species [32] [45]-[47]. Between 1870 and 1960, management agencies responded by stocking over 32 billion lake whitefish fry and 6 billion cisco fry, but this effort did not arrest population declines, perhaps because stocking levels had been too low [40] or stocked fish had a high mortality [48]. Chemical control of invasive sea lamprey (Petromyzon marinus), and biological control of invasive fish species through the intentional stocking of Pacific salmon, led to improved survival of lake whitefish and the subsequent recovery of fisheries for this species during the latter half of the $20^{\text {th }}$ century [41]. Unlike lake whitefish, cisco never recovered in the lower Great Lakes of Michigan, Erie and Ontario [44]. Annual yields between 1993-2004 averaged 0.64 million kg, with the bulk (98\%) harvested from Lake Superior [43] [44].

\section{Impacts of Fishing on Whitefish Diversity}

In marine ecosystems, overfishing has caused the collapse of many species [49]. Overfishing has also been documented in lakes, especially those where both commercial and recreational fisheries operate [37] [50]. Fishing pressure impacts not only stock abundance, but may also affect the composition and structure of fish assemblages and promote hybridization among species and morphs. In the Laurentian Great Lakes of North America, coregonid stock depletion due to overfishing was recorded as early as the end of the nineteenth century, and later by the 1930s due to sea lamprey invasion [51]. Between the 1940s and the 1960s, 15 coregonid populations became extinct [52]. In Lake Michigan, Smith (1964) documented the decline in abundance of all, but the smallest-bodied of deepwater ciscoes, bloater, which he attributed to 1) an intense size-selective fishery on largebodied deepwater ciscoes, 2) reduced lake trout and large-bodied deepwater cisco abundance resulting from sea lamprey predation, 3) the removal of competition and predation pressure allowing bloater to greatly expand their numbers and range, and 4) the occurrence of new "hybrid" ciscoes being reported, suggesting introgressive hybridization.

Fishing induced declines in abundance can also change the nature and strength of interactions between species. As an example, fishing pressure indirectly affected diversity by modifying the regulatory mechanisms (competition and predation) and led to the restructuration of fish composition and reputed hybridization events in both Lake Michigan [53] and Lake Huron [54]. The latter authors showed that gill-raker numbers, that were initially characteristic of individual species, converged toward intermediate values. They assumed that bloater abundance remained high in the 1980s, whereas cisco became rare because of overfishing and sea lamprey predation making cisco more likely to mate with bloater. In contrast, previous studies attributed the cisco decline in Western Lake Superior to increased competition for food with bloater and rainbow smelt at the critical larval stage [55], in addition to overfishing [56] [57] and recruitment failure [44] [47]. The decline of shortjaw ciscoes in Lake Superior has been attributed to commercial fishing [58], although [17] later argued that this decline was a result of increased resource competition with recovered cisco populations. 
Although signs of eutrophication were evident at the early part of the $20^{\text {th }}$ century in Lakes Erie, Michigan, and Ontario [59], this was not at a high enough level to hamper fish populations. Commercial fishing on Lake Michigan likely started as early as the 1820s and concerns over depleted lake whitefish populations were common by the 1870s [51] [60], prior to any evidence of eutrophication [59]. Decline and recovery of lake whitefish populations in Lakes Superior, Michigan, Huron and Ontario were tightly correlated with arrival and then control of invasive sea lamprey, suggesting predation by sea lamprey was a major factor in lake whitefish dynamics [61]. The largest commercial catches of cisco were from Lake Erie in 1910s and two other pulses were observed in the 1930s and 1940s from very strong year class [44] [62]. In Lake Ontario, strong year classes of cisco were found into the late 1930s [63], and in Lake Michigan, cisco did not collapse until the 1950s and 1960s when major spawning areas experienced very low dissolved oxygen concentrations during the winter when eggs incubate [32] [61]. Eutrophication only became a major concern by the 1960s and may have exacerbated fisheries decline from overfishing and invasive species [51].

Finally, when fishing practices target fish according to particular phenotypic traits such as their size or their distribution, artificial selection may occur and counter natural selection [64]. This process is referred to as fishery induced genetic evolution or more generally "unnatural" selection [65]. Various traits are likely to evolve under intense fishing pressure and studies on exploited fish populations have reported maturation at younger ages and smaller sizes, increased fecundity, and loss of genetic diversity [66]. Several studies have revealed evolutionary changes in whitefish as a result of fishing including lower growth rates, and higher fecundity [67][70].

\section{Impacts of Stocking on Whitefish Diversity}

Introduced populations can influence taxonomic diversity by either displacing or coexisting with indigenous populations [71]. Loss of diversity following species introduction may occur through different mechanisms such as competition, predation, habitat modification or genetic extinction through introgression [72] [73]. Recently, [28] showed that introduced pelagic vendace (Coregonus albula) relegated a native pelagic whitefish morph into the benthic habitat already occupied by a native benthivorous morph causing subsequent genetic admixture and homogenization of these whitefish morphs. This example suggests that fishery management can cascade and lead to speciation reversal.

In the last decades, the impact of hatchery stockings on wild populations has become a critical issue in conservation ecology [1] [74]. However, understanding that stocking of coregonids from other lakes could impact diversity was only discovered after the damage had already occurred [10]. Examples of hybridization following coregonids introduction are numerous in Europe. Hybridization often caused species identification problems which led to stocking errors leading to further management problems [75], imbalanced exploitation of native vs hybrids forms [76] or rearing of different populations in the same facilities increasing the risk of ex-situ hybridization or erroneous stocking [77]. As an example, hybrids of the Coregonus peled with the indigenous European whitefish (C. lavaretus) are common in numerous lakes [75]. Native whitefish hybridized with introduced vendace C. albula, resulting in individuals with intermediate morphological and ecological characteristics that were also able to survive and reproduce [78]. We now know that genotypic composition of whitefish populations are strongly affected by stocking practices [10] [39] [79]. Today in Europe, especially in the central Alpine region, Coregonus populations are a blend of indigenous and transplanted forms strongly influenced by intense transplantations. Such observations led [39] to state that "indiscriminant and undocumented stocking during the last 100 years has added confusion already extant from naturally occurring cryptic and sibling species within the lakes". Furthermore, experimental crossing of lake whitefish morphs has revealed many interesting results indicating how hybridizations cause increasing embryonic mortality, developmental problems and change hatching times [80]-[82]. Finally, supportive breeding is purported to better retain genetic diversity, it may also adversely affect diversity by stimulating intraspecific selection [83] [84].

For example, Lake Constance has been stocked with hatchery-bred coregonid larvae for over a century. [85] found that hatchery fish represented $60 \%$ of the young-of-year fish collected in 2003. These offspring came from a restricted number of genitors [68], and the estimated contribution of stocked fish to overall cohort abundance can be as high as $83 \%$ [86]. Considering such results, [85] warned that continued stocking could affect the ability of the population to adapt to environmental changes, because natural selection processes were being artificially circumvented. Indeed, management activities such as changes in system productivity, size-selective har- 
vest and massive stocking events have all been shown to influence coregonid reproductive traits [67]-[69]. As an example, when gillnets are used exclusively to collect adults for breeding, females with larger girth and hence higher fecundity will disproportionately contribute offspring to the stocked cohort. Stocking could thus sustain a genetic selection towards higher fecundity and slower growth, though a recent study showed that in Lake Constance such activities did not alter the genetic diversity of the species C. wartmanni [87]. Others have argued that such practices may impoverish genetic diversity and might influence population structure and production [83] [84].

Finally, another problem associated with hatchery-reared fish is the accidental hybridization of different native sympatric species that in nature do not have the opportunity to mix, because of strong temporal or spatial differentiation of their spawning habitat [10] [26]. Upon closer examination of reproductive biology, the data on genetic differentiation among C. wartmanni and C. macrophthalmus in Lake Constance reported by [14] highlights the possible role of genetic admixture in hatcheries for the loss of genetic diversity. The observed reduction in genetic diversity is unlikely due to a reduction of the reproductive niche spaces and thus to hybridization as suggested by [14]. Although the two species have rather similar spawning periods, $C$. wartmanni is an open water spawner that sheds its eggs near the surface in the pelagic zone of Lake Constance after which they sink to the lake bottom, while C. macrophthalmus is a bottom spawner which utilizes the lake shoreline. Both species spawn at the same time in late November/early December, and they continued to use their respective spawning habitats even during the lake's eutrophic stage. No evidence exists, however, to suggest the spawning locations of these species changed as Lake Constance became more eutrophic. Although hybridization between $C$. wartmanni and C. macrophthalmus in their natural environment is possible, their spawning sites did not converge in a way similar to those of bottom-spawning species, where deeper-spawning species were forced to use shallower sites when oxygen levels in deep water became deficient. Evidence exists, however, that hybridization between C. wartmanni and C. macrophthalmus occurred in hatcheries that provided fish for Lake Constance. For more than 100 years, larvae of both species were propagated in hatcheries from eggs and milt obtained during the spawning season, and larvae were stocked into the lake in quantities that increased from around 30 million during the 1930s to more than 300 million in the 1980s and 1990s [86]. For several decades the collection of both species took place simultaneously, and individuals of the two species were often stripped of eggs and milt at the same time, promoting the possibility for hybridization. Only in the late 1990s was this practice finally banned, with gamete collection of the two species now occurring on different dates. Hence, unwanted artificial hybridization could have easily occurred over several decades, and may have contributed to the observed decline in genetic diversity [88].

\section{Impact of the Interactions between Habitat Degradation and Management Practices}

Eutrophication has been shown to impact diversity [14], but in lakes where fisheries are intensely managed, the combination of stressors rather than habitat degradation alone has to be considered to fully understand the mechanisms causing lost diversity. This is illustrated by the following case studies.

The loss of diversity in Lakes Greifen and Pfäffiker (Switzerland) is a striking example of the combined effects of eutrophication and stocking. These lakes were stocked with exogenous species from Lake Zurich [39]. In Lakes Greifen and Pfäffiker, reduced oxygen concentrations, due to a highly eutrophic state, may have limited natural reproduction of the indigenous species [31], thus providing an empty ecological niche for the exogenous individuals to exploit. The outcome of competition can differ depending on lake, but in these two lakes, genetic analyses indicated that the introduced populations displaced the original population, with allelic and genotypic frequencies of current coregonids in Lakes Greifen and Pfäffiker not varying significantly from the Lake Zurich coregonids that served as the donor population [39].

In Lake Geneva, previous studies and historical documents on whitefish stocking suggest that the combination of heavy fishing pressure and stocking practices are more likely mechanisms to explain the decline in coregonid diversity. Two native coregonid forms (Coregonus fera and Coregonus hiemalis) described by [89] and [90], respectively, were native to Lake Geneva and supported fisheries. After 1880, the number of fishermen dramatically increased, and the advent of new fishing nets with smaller mesh sizes led to greater catches of smaller fish [36]. The introduction of exogenous species started in 1881, but in 1896, concerns that stocking of non-native coregonids was unwise have been raised [91]. As late as 1900, the two indigenous species were still present in 
Lake Geneva [92], but yields rapidly decreased from 84 to less than 4 tons between 1897 and 1914 [36]. During this period, Lake Geneva was still oligotrophic [36]. When countering the whitefish collapse, managers chose to import coregonids from other lakes over regulating the fishing effort. Yield statistics, based on obligatory declarations, began in France in 1897 and in Switzerland in 1943. These data cannot be used to track changes in the relative abundance of stocks over time but these statistics do provide insight about extractions. Based on the dramatic decline in yields, several studies concluded that heavy fishing pressure led to the collapse of the native Lake Geneva coregonid populations [36] [37] [91], with massive stocking of whitefish from other lakes, mainly from Neuchâtel [36], attributing to their further disappearance [91]. By the mid-20 $0^{\text {th }}$ century, coregonids originally from Lake Neuchatel dominated the commercial catches, C. hiemalis was considered extinct, and C. fera were nearing extinction [91]. It was only later in the 1960s and 1970s that annual mean phosphorus concentration increased from $10 \mu \mathrm{g} / \mathrm{L}$ to $90 \mu \mathrm{g} / \mathrm{L}$ [93]. By 1972, Lake Geneva was considered eutrophic, and the two indigenous species no longer existed [37]. Stocking has since stopped, with genetic analyses showing the current Lake Geneva population differs genetically from other populations in Switzerland, with clear divergence from its source population [39].

\section{Conclusions}

Our examples demonstrate that coregonid diversity loss may have occurred in several lakes where evidence of eutrophication is weak or occurred much later in time. Loss of diversity in these lakes may be attributed to the interplay of various factors including management practices. We emphasize the role management can play in the disappearance of species and show that eutrophication can further impact fish diversity in lake weakened by fisheries management.

Finally, our review suggests that fish conservation policies could beneficially consider the relative importance and interactions of stressors, including management practices, as drivers for lost diversity. Our examples from both European and North American lakes suggest that the effects of fishing and stocking can drive diversity losses. As stated by [14], the lack of traceability of fisheries practices made it difficult to account for these factors in statistical analyses. However, there is danger in excluding factors on the basis that empirical data are incomplete. Although it can be challenging and time consuming to compile, it is important to try and include such important factors that can influence ecosystem changes, especially in the realm of fisheries science where scientific outcomes may guide management actions.

\section{Acknowledgements}

The authors thank Guillaume Evanno and anonymous referees for their comments which have contributed to the improvement of the manuscript. Any use of trade, product, or firm names is for descriptive purposes only and does not imply endorsement by the U.S. Government. This article is contribution number 1949 of the Great Lakes Science Center.

\section{References}

[1] Utter, F. (1998) Genetic Problems of Hatchery-Reared Progeny Released into the Wild, and How to Deal with Them. Bulletin of Marine Science, 62, 623-640.

[2] Naylor, R.L., Goldburg, R.J., Primavera, J.H., Kautsky, N., Beveridge, M.C.M., Clay, J., Folke, C., Lubchenco, J., Mooney, H. and Troell, M. (2000) Effect of Aquaculture on World Fish Supplies. Nature, 405, 1017-1024. http://dx.doi.org/10.1038/35016500

[3] Hutchings, J.A. and Fraser, D.J. (2008) The Nature of Fisheries- and Farming-Induced Evolution. Molecular Ecology, 17, 294-313. http://dx.doi.org/10.1111/j.1365-294X.2007.03485.x

[4] Cowx, I.G. and Gerdeaux, D. (2004) The Effects of Fisheries Management Practices on Freshwater Ecosystems. Fisheries Management and Ecology, 11, 145-151. http://dx.doi.org/10.1111/j.1365-2400.2004.00411.X

[5] Hsieh, C.-H., Reiss, C.S., Hunter, J.R., Beddington, J.R., May, R.M. and Sugihara, G. (2006) Fishing Elevates Variability in the Abundance of Exploited Species. Nature, 443, 859-862. http://dx.doi.org/10.1038/nature05232

[6] Lobon-Cervia, J. (2009) Why, When and How Do Fish Populations Decline, Collapse and Recover? The Example of Brown Trout (Salmo trutta) in Rio Chaballos (Northwestern Spain). Freshwater Biology, 54, 1149-1162. http://dx.doi.org/10.1111/j.1365-2427.2008.02159.x 
[7] Perry, R.I., Cury, P., Brander, K., Jennings, S., Moellmann, C. and Planque, B. (2010) Sensitivity of Marine Systems to Climate and Fishing: Concepts, Issues and Management Responses. Journal of Marine Systems, 79, 427-435. http://dx.doi.org/10.1016/j.jmarsys.2008.12.017

[8] Ter Hofstede, R. and Rijnsdorp, A.D. (2011) Comparing Demersal Fish Assemblages between Periods of Contrasting Climate and Fishing Pressure. ICES Journal of Marine Science, 68, 1189-1198. http://dx.doi.org/10.1093/icesjms/fsr053

[9] Sandlund, O.T., Hesthagen, T. and Brabrand, A. (2013) Coregonid Introductions in Norway: Well-Intended and Successful, but Destructive. Fundamental and Applied Limnology. Special Issues. Advances in Limnology, 64, 345-362. http://dx.doi.org/10.1127/1612-166X/2013/0064-0013

[10] Winkler, K.A., Pamminger-Lahnsteiner, B., Wanzenböck, J. and Weiss, S. (2011) Hybridization and Restricted Gene Flow between Native and Introduced Stocks of Alpine Whitefish (Coregonus sp.) across Multiple Environments. Molecular Ecology, 20, 456-472. http://dx.doi.org/10.1111/j.1365-294X.2010.04961.x

[11] Cowx, I.G. (1998) Stocking and Introduction of Fish. Fishing News Books, Oxford, 456 p.

[12] Cowx, I.G. (2002) Analysis of Threats to Freshwater Fish Conservation: Past and Present Challenges. In: CollaresPereira, M.J., Cowx, I.G. and Coelho, M.M., Eds., Conservation of Freshwater Fish: Options for the Future, Blackwell Science, Oxford, 201-220.

[13] Hauser, L., Adcock, G.J., Smith, P.J., Bernal, R.J.H. and Carvalho, G.R. (2002) Loss of Microsatellite Diversity and Low Effective Population Size in an Overexploited Population of New Zealand Snapper (Pagrus auratus). Proceedings of the National Academy of Sciences of the United States of America, 99, 11742-11747. http://dx.doi.org/10.1073/pnas.172242899

[14] Vonlanthen, P., Bittner, D., Hudson, A.G., Young, K.A., Müller, R., Lundsgaard-Hansen, B., Roy, D., Di Piazza, S., Largiader, C.R. and Seehausen, O. (2012) Eutrophication Causes Speciation Reversal in Whitefish Adaptive Radiations. Nature, 482, 357-362. http://dx.doi.org/10.1038/nature10824

[15] Todd, T.N. and Steinhilber, M. (2002) Diversity in Shortjaw Cisco (Coregonus zenithicus) in North America. Archiv für Hydrobiologie, Special Issues, Advances in Limnology, 57, 517-525.

[16] Vonlanthen, P., Roy, D., Hudson, A.G., Largiader, C.R., Bittner, D. and Seehausen, O. (2009) Divergence along a Steep Ecological Gradient in Lake Whitefish (Coregonus sp.). Journal of Evolutionary Biology, 22, 498-514. http://dx.doi.org/10.1111/j.1420-9101.2008.01670.x

[17] Bronte, C.R., Hoff, M.H., Gorman, O.T., Thogmartin, W.E., Schneeberger, P.J. and Todd, T.N. (2010) Decline of the Shortjaw Cisco in Lake Superior: The Role of Overfishing and Risk of Extinction. Transactions of the American Fisheries Society, 139, 735-748. http://dx.doi.org/10.1577/T09-019.1

[18] Siwertsson, A., Knudsen, R., Kahilainen, K.K., Præbel, K., Primicerio, R. and Amundsen, P.A. (2010) Sympatric Diversification as Influenced by Ecological Opportunity and Historical Contingency in a Young Species Lineage of Whitefish. Evolutionary Ecology Research, 12, 929-947.

[19] Bernatchez, L. (2004) Ecological Theory of Adaptive Radiation: Empirical Assessment from Coregonine Fishes (Salmoniformes). In: Hendry, A.P. and Stearns, S.C., Eds., Evolution Illuminated: Salmon and Their Relatives, Oxford University Press, Oxford, 175-207.

[20] Hudson, A.G., Vonlanthen, P., Müller, R. and Seehausen, O. (2007) Review: The Geography of Speciation and Adaptive Radiation of Coregonines. Fundamental and Applied Limnology, Special Issues Advances Limnology, 60, 111-146.

[21] Præbel, K., Knudsen, R., Siwertsson, A., Karhunen, M., Kahilainen, K.K., Ovaskainen, O., Østbye, K., Peruzzi, S., Fevolden, S.-E. and Amundsen, P.-A. (2013) Ecological Speciation in Postglacial European Whitefish: Rapid Adaptive Radiations into the Littoral, Pelagic, and Profundal Lake Habitats. Ecology and Evolution, 3, 4970-4986. http://dx.doi.org/10.1002/ece3.867

[22] Svärdson, G. (1979) Speciation of Scandinavian Coregonus. Report of the Institute of Freshwater Research, 57, 3-95.

[23] Turgeon, J., Estoup, A. and Bernatchez, L. (1999) Species Flock in the North American Great Lakes: Molecular Ecology of Lake Nipigon Ciscoes (Teleostei: Coregonidae: Coregonus). Evolution, 53, 1857-1871. http://dx.doi.org/10.2307/2640446

[24] Harrod, C., Mallela, J. and Kahilainen, K.K. (2010) Phenotype-Environment Correlations in a Putative Whitefish Adaptive Radiation. Journal of Animal Ecology, 79, 1057-1068. http://dx.doi.org/10.1111/j.1365-2656.2010.01702.x

[25] Kahilainen, K.K., Siwertsson, A., Gjelland, K.O., Knudsen, R., Bøhn, T. and Amundsen, P.-A. (2011) The Role of Gill Raker Number Variability in Adaptive Radiation of Coregonid Fish. Evolutionary Ecology, 25, 573-588. http://dx.doi.org/10.1007/s10682-010-9411-4

[26] Wanzenböck, J., Pamminger-Lahnsteiner, B., Winkler, K. and Weiss, S.J. (2012) Experimental Evaluation of the Spawning Periods of Whitefish (Coregonus lavaretus Complex) in Lake Mondsee, Austria. Fundamental and Applied Limnology, Special Issues, Advances in Limnology, 63, 89-97. 
[27] Turgeon, J. and Bernatche, L. (2003) Reticulate Evolution and Phenotypic Diversity in North American Ciscoes, Coregonus ssp. (Teleostei: Salmonidae): Implications for the Conservation of an Evolutionary Legacy. Conservation Genetics, 4, 67-81. http://dx.doi.org/10.1023/A:1021860910719

[28] Bhat, S., Amundsen, P.-A., Knudsen, R., Gjelland, K.O., Fevolden, S.-E., Bernatchez, L. and Præbel, K. (2014) Speciation Reversal in European Whitefish (Coregonus lavaretus (L.)) Caused by Competitor Invasion. PLoS ONE, 9, e91208. http://dx.doi.org/10.1371/journal.pone.0091208

[29] Rask, M., Vuorinen, P.J., Raitaniemi, J., Vuorinen, M., Lappalainen, A. and Peuranen, S. (1992) Whitefish Stocking in Acidified Lakes: Ecological and Physiological Responses. Hydrobiologia, 243-244, 277-282. http://dx.doi.org/10.1007/BF00007043

[30] Vuorinen, P.J., Keinänen, M., Lappalainen, A., Peuranen, S. and Rask, M. (2004) Physiological Status of Whitefish (Coregonus lavaretus pallasi) Prior to Spawning in Lakes of Differing Acidity. Aquatic Sciences, 66, 305-314. http://dx.doi.org/10.1007/s00027-004-0696-7

[31] Müller, R. (1992) Trophic State and Its Implications for Natural Reproduction of Salmonid Fish. Hydrobiologia, 243/244, 261-268. http://dx.doi.org/10.1007/BF00007041

[32] Madenjian, C.P., Rutherford, E.S., Blouin, M.A., Sederberg, B.J. and Elliott, J.R. (2011) Spawning Habitat Unsuitability: An Impediment of Cisco Rehabilitation in Lake Michigan? North American Journal of Fisheries Management, 31, 905-913. http://dx.doi.org/10.1080/02755947.2011.632065

[33] Eckmann, R. (2013) A Review of the Population Dynamics of Coregonids in European Alpine Lakes. Fundamental and Applied Limnology, Special Issues, Advances in Limnology, 64, 3-24. http://dx.doi.org/10.1127/1612-166X/2013/0064-0002

[34] Bittner, D., Excoffier, L. and Largiader, C.R. (2010) Patterns of Morphological Changes and Hybridization between Sympatric Whitefish Morphs (Coregonus spp.) in a Swiss Lake: A Role for Eutrophication? Molecular Ecology, 19, 2152-2167. http://dx.doi.org/10.1111/j.1365-294X.2010.04623.x

[35] Heer, L. (1983) Der Sempachersee: Die Fischerei in früheren Zeit, sein heutiger Zustand und die Sanierungsmassnahmen. Schriftenreihe Fischerei, 41, 1-20.

[36] Bardel, M. (1956) La pêche professionnelle des corégones dans les eaux françaises du lac Léman. Bulletin Français de Pisciculture, 182, 26-36. http://dx.doi.org/10.1051/kmae:1956003

[37] Laurent, P.J. (1972) Lac Léman: Effects of Exploitation, Eutrophication, and Introductions on the Salmonid Community. Journal of the Fisheries Research Board of Canada, 29, 867-875. http://dx.doi.org/10.1139/f72-130

[38] Grimaldi, E. and Nümann, W. (1972) The Future of Salmonid Communities in the European Subalpine Lakes. Journal of the Fisheries Research Board of Canada, 29, 931-936. http://dx.doi.org/10.1139/f72-135

[39] Douglas, M.R. and Brunner, P.C. (2002) Biodiversity of Central Alpine Coregonus (Salmoniformes): Impact of OneHundred Years of Management. Ecological Applications, 12, 154-172. http://dx.doi.org/10.1890/1051-0761(2002)012[0154:BOCACS]2.0.CO;2

[40] Todd, T.N. (1986) Artificial Propagation of Coregonines in the Management of the Laurentian Great Lakes. Archiv für Hydrobiologie, Special Issue, Advanced Limnology, 22, 31-50.

[41] Ebener, M.P. (1997) Recovery of Lake Whitefish Populations in the Great Lakes. Fisheries, 22, 18-20.

[42] Milner, J.W. (1874) Report on the Fisheries of the Great Lakes: The Result of Inquiries Prosecuted in 1871 and 1872 Report of US Fish Commissioner of Fish and Fisheries for 1872 and 1873, 78 p.

[43] Baldwin, N.A., Saalfeld, R.W., Dochoda, M.R., Buettner, H.J. and Eshenroder, R.L. (2009) Commercial Fish Production in the Great Lakes 1867-2006. Great Lakes Fishery Commission. www.glfc.org/databases/commercial/commerc.php

[44] Stockwell, J.D., Ebener, M.P., Black, J.A., Gorman, O.T., Hrabik, T.R., Kinnunen, R.E., Mattes, W.P., Oyadomari, J.K., Schram, S.T., Schreiner, D.R., Seider, M.J., Sitar, S.P. and Yule, D.L. (2009) A Synthesis of Cisco Recovery in Lake Superior: Implications for Native Fish Rehabilitation in the Laurentian Great Lakes. North American Journal of Fisheries Management, 29, 626-652. http://dx.doi.org/10.1577/M08-002.1

[45] Christie, W.J. (1972) Lake Ontario: Effects of Exploitation, Introductions, and Eutrophication on the Salmonid Community. Journal of the Fisheries Research Board of Canada, 29, 913-929. http://dx.doi.org/10.1139/f72-134

[46] Wells, L. and McLain, A.L. (1973) Lake Michigan-Man’s Effects on Native Fish Stocks and Other Biota. Great Lakes Fishery Commission, Technical Report No 20.

[47] Gorman, O.T. (2012) Successional Change in the Lake Superior Fish Community: Population Trends in Ciscoes, Rainbow Smelt, and Lake Trout, 1958-2008. Fundamental and Applied Limnology, Special Issues, Advances in Limnology, 63, 337-362.

[48] Christie, W.J. (1963) Effects of Artificial Propagation and the Weather on Ecruitment in the Lake Ontario Whitefish 
Fishery. Journal of the Fisheries Research Board of Canada, 20, 597-646. http://dx.doi.org/10.1139/f63-043

[49] Pauly, D., Christensen, V., Guénette, S., Pitcher, T.J., Rashid, Sumaila U., Walters, C.J., Watson, R. and Zeller, D. (2002) Towards Sustainability in World Fisheries. Nature, 418, 689-695. http://dx.doi.org/10.1038/nature01017

[50] Lévêque, C., Oberdorff, T., Paugy, D., Stiassny, M.L.J. and Tedesco, P.A. (2008) Global Diversity of Fish (Pisces) in Freshwater. Hydrobiologia, 595, 545-567. http://dx.doi.org/10.1007/s10750-007-9034-0

[51] Beeton, A.M. (2002) Large Freshwater Lakes: Present State, Trends, and Future. Environmental Conservation, 29, 2138. http://dx.doi.org/10.1017/S0376892902000036

[52] Phillips, R.-B. and Ehlinger, T.-J. (1995) Evolutionary and Ecological Considerations in the Re-Establishment of Great Lakes Coregonid Fishes. American Fisheries Society Symposium, 17, 133-144.

[53] Smith, S.H. (1964) Status of the Deepwater Cisco Population of Lake Michigan. Transactions of the American Fisheries Society, 93, 155-163. http://dx.doi.org/10.1577/1548-8659(1964)93[155:SOTDCP]2.0.CO;2

[54] Todd, T.N. and Stedman, R.M. (1989) Hybridization of Ciscoes (Coregonus spp.) in Lake Huron. Canadian Journal of Zoology, 67, 1679-1685. http://dx.doi.org/10.1139/z89-241

[55] Anderson, E.D. and Smith, Jr., L.L. (1971) Factors Affecting Abundance of Lake Herring (Coregonus artedii Lesueur) in Western Lake Superior. Transactions of the American Fisheries Society, 100, 691-707. http://dx.doi.org/10.1577/1548-8659(1971)100<691:FAAOLH>2.0.CO;2

[56] Lawrie, A.H. and Rahrer, J.F. (1972) Lake Superior: Effects of Exploitation and Introductions on the Salmonid Community. Journal of the Fisheries Research Board of Canada, 29, 765-776. http://dx.doi.org/10.1139/f72-121

[57] Selgeby, J.H. (1982) Decline of Lake Herring (Coregonus artedii) in Lake Superior: An Analysis of the Wisconsin Herring Fishery, 1936-1978. Canadian Journal of Fisheries and Aquatic Sciences, 39, 554-563. http://dx.doi.org/10.1139/f82-079

[58] Gorman, O.T. and Todd, T.N. (2007) History of the Shortjaw Cisco (Coregonus zenithicus) in Lake Superior, 18952003. Fundamental and Applied Limnology, Special Issues, Advances in Limnology, 60, 433-458.

[59] Beeton, A.M. (1965) Eutrophication of the St. Lawrence Great Lakes. Limnology and Oceanography, 10, $240-254$. http://dx.doi.org/10.4319/lo.1965.10.2.0240

[60] Brown, R., Ebener, M. and Gorenflo, T. (1999) Great Lakes Commercial Fisheries: Historical Overview and Prognosis for the Future. In: Taylor, W. and Ferreri, C., Eds., Great Lakes Fisheries Policy and Management, Michigan State University Press, East Lansing, 307-354.

[61] Madenjian, C.P., O’Gorman, R., Bunnell, D.B., Argyle, R.L., Roseman, E.F., Warner, D.M., Stockwell, J.D. and Stapanian, M.A. (2008) Adverse Effects of Alewives on Great Lakes Communities. North American Journal of Fisheries Management, 28, 263-282. http://dx.doi.org/10.1577/M07-012.1

[62] Baldwin, N.S. and Saalfeld, R.W. (1962) Commercial Fish Production in the Great Lakes 1867-1960. Great Lakes Fishery Commission Technical Report No. 3, 166 p.

[63] Christie, W.J. (1973) A Review of the Changes in the Fish Species Composition of Lake Ontario. Great Lakes Fishery Commission Technical Report 23.

[64] Kuparinen, A. and Merila, J. (2007) Detecting and Managing Fisheries-Induced Evolution. Trends in Ecology and Evolution, 22, 652-659. http://dx.doi.org/10.1016/j.tree.2007.08.011

[65] Allendorf, F.W. and Hard, J.J. (2009) Human-Induced Evolution Caused by Unnatural Selection through Harvest of Wild Animals. Proceedings of the National Academy of Sciences of the United States of America, 106, 9987-9994. http://dx.doi.org/10.1073/pnas.0901069106

[66] Jørgensen, C., Enberg, K., Dunlop, E.S., Arlinghaus, R., Boukal, D.S., Brander, K., Ernande, B., Gaerdmark, A., Johnston, F., Matsumura, S., Pardoe, H., Raab, K., Silva, A., Vainikka, A., Dieckmann, U., Heino, M. and Rijnsdorp, A.D. (2007) Ecology-Managing Evolving Fish Stocks. Science, 318, 1247-1248. http://dx.doi.org/10.1126/science.1148089

[67] Nusslé, S., Bornand, C.N. and Wedekind, C. (2009) Fishery-Induced Selection on an Alpine Whitefish: Quantifying Genetic and Environmental Effects on Individual Growth Rate. Evolutionary Applications, 2, 200-208. http://dx.doi.org/10.1111/j.1752-4571.2008.00054.x

[68] Thomas, G., Quoss, H., Hartmann, J. and Eckmann, R. (2009) Human-Induced Changes in the Reproductive Traits of Lake Constance Common Whitefish (Coregonus lavaretus). Journal of Evolutionary Biology, 22, 88-96. http://dx.doi.org/10.1111/j.1420-9101.2008.01622.x

[69] Nusslé, S., Brechon, A. and Wedekind, C. (2011) Change in Individual Growth Rate and Its Link to Gill-Net Fishing in Two Sympatric Whitefish Species. Evolutionary Ecology, 25, 681-693. http://dx.doi.org/10.1007/s10682-010-9412-3

[70] Thomas, G. and Eckmann, R. (2012) Reproduction vs. Growth: Indications for Altered Energy Fluxes in Lake Con- 
stance Whitefish through Size-Selective Fishery. Fundamental and Applied Limnology, Special Issues, Advances in Limnology, 63, 147-157.

[71] Lövei, G.L. (1997) Biodiversity: Global Change through Invasion. Nature, 388, 627-628. http://dx.doi.org/10.1038/41665

[72] Rhymer, J.M. and Simberloff, D. (1996) Extinction by Hybridization and Introgression. Annual Review of Ecological Systems, 27, 83-109. http://dx.doi.org/10.1146/annurev.ecolsys.27.1.83

[73] Cucherousset, J. and Olden, J.D. (2011) Ecological Impacts of Non-Native Freshwater Fishes. Fisheries, 36, $215-230$. http://dx.doi.org/10.1080/03632415.2011.574578

[74] Christie, M.R., Marine, M.L., French, R.A. and Blouin, M.S. (2012) Genetic Adaptation to Captivity Can Occur in a Single Generation. Proceedings of the National Academy of Sciences of the United States of America, 109, 238-242. http://dx.doi.org/10.1073/pnas.1111073109

[75] Luczynski, M., Falkowski, S., Vuorinen, J. and Jankun, M. (1992) Genetic Identification of European Whitefish (Coregonus lavaretus), Peled (C. peled) and Their Hybrids in Spawning Stocks of Ten Polish Lakes. Polskie Archiwum Hydrobiologii, 39, 571-577.

[76] Gerdeaux, D., Gerald, P., Grollinger, B. and Nameche, T. (1998) Survey of Coregonid Stocking in Two Reservoirs in Belgium. Archiv für Hydrobiologie, Special Issues, Advances in Limnology, 50, 487-495.

[77] Dierking, J., Phelps, L., Præbel, K., Ramm, G., Prigge, E., Borcherding, J., Brunke, M. and Eizaguirre, C. (2014) Anthropogenic Hybridization between Endangered Migratory and Commercially Harvested Stationary Whitefish Taxa (Coregonus spp.). Evolutionary Applications, 7, 1068-1083. http://dx.doi.org/10.1111/eva.12166

[78] Kahilainen, K.K., Østbye, K., Harrod, C., Shikano, T., Malinen, T. and Merilä, J. (2011) Species Introduction Promotes Hybridization and Introgression in Coregonus: Is There Sign of Selection against Hybrids? Molecular Ecology, 20, 3838-3855. http://dx.doi.org/10.1111/j.1365-294X.2011.05209.x

[79] Hudson, A.G., Vonlanthen, P. and Seehausen, O. (2011) Rapid Parallel Adaptive Radiations from a Single Hybridogenic Ancestral Population. Proceeding of the Royal Society London B, 278, 58-66. http://dx.doi.org/10.1098/rspb.2010.0925

[80] Lu, G. and Bernatchez, L. (1998) Experimental Evidence for Reduced Hybrid Viability between Dwarf and Normal Ecotypes of Lake Whitefish (Coregonus clupeaformis Mitchill). Proceeding of the Royal Society London B, 265, 10251030. http://dx.doi.org/10.1098/rspb.1998.0394

[81] Rogers, S.M. and Bernatchez, L. (2006) The Genetic Basis of Intrinsic and Extrinsic Post-Zygotic Reproductive Isolation Jointly Promoting Speciation in the Lake Whitefish Species Complex (Coregonus clupeaformis). Journal of Evolutionary Biology, 19, 1979-1994. http://dx.doi.org/10.1111/j.1420-9101.2006.01150.x

[82] Bernatchez, L., Renaut, S., Whiteley, A.R., Derome, N., Jeukens, J., Landry, L., Lu, G., Nolte, A.W., Østbye, K., Rogers, S.M. and St-Cyr, J. (2010) On the Origin of Species: Insights from the Ecological Genomics of Lake Whitefish. Philosophical Transactions of the Royal Society B, 365, 1783-1800. http://dx.doi.org/10.1098/rstb.2009.0274

[83] Wang, J.L. and Ryman, N. (2001) Genetic Effects of Multiple Generations of Supportive Breeding. Conservation Biology, 15, 1619-1631. http://dx.doi.org/10.1046/j.1523-1739.2001.00173.x

[84] Ford, M.J. (2002) Selection in Captivity during Supportive Breeding May Reduce Fitness in the Wild. Conservation Biology, 16, 815-825. http://dx.doi.org/10.1046/j.1523-1739.2002.00257.x

[85] Eckmann, R., Kugler, M. and Ruhlé, C. (2007) Evaluating the Success of Large-Scale Whitefish Stocking at Lake Constance. Fundamental and Applied Limnology, Special Issues, Advances in Limnology, 60, 361-368.

[86] Eckmann, R. (2012) Massive Stocking with Hatchery Larvae May Constrain Natural Recruitment of Whitefish Stocks and Induce Unwanted Evolutionary Changes. Fundamental and Applied Limnology, Special Issues, Advances in Limnology, 63, 325-336.

[87] Gum, B., Geist, J., Eckenfels, S. and Brinker, A. (2014) Genetic Diversity of Upper Lake Constance Whitefish Coregonus spp. under the Influence of Fisheries: A DNA Study Based on Archived Scale Samples from 1932, 1975 and 2006. Journal of Fish Biology, 84, 1721-1739. http://dx.doi.org/10.1111/jfb.12393

[88] Eckmann, R. (2015) Absence of Intrinsic Post-Zygotic Incompatibilities in Artificial Crosses between Sympatric Coregonid Species from Upper Lake Constance. Journal of Fish Biology, 86, 1601-1611. http://dx.doi.org/10.1111/jfb.12673

[89] Jurine, L. (1825) Histoire abrégée des poissons du lac Léman. Mémoires de la Société de Physique et d'Histoire Naturelle de Genève, 3, 133-235.

[90] Fatio, V. (1882) Faune des vertébrés de la Suisse. Histoire naturelle des poissons. H. Georg, Genève et Bâle. Vol. 1, 1892: 786 p. Vol. 2, 1890: 576 p.

[91] Dottrens, E. (1950) Le Corégone actuel du Léman. Revue Suisse de Zoologie, 37, 789-813. 
[92] Forel, F.A. (1904) Le Léman. Monographie Limnologique. Rouge and Co., Lausanne. Vol. 1, $1892: 543$ p. Vol. 2, 1895: 651 p. Vol. 3, 1909, 715 p.

[93] Anneville, O., Ginot, V., Druart, J.C. and Angeli, N. (2002) Long-Term Study (1974-1998) of Seasonal Changes in the Phytoplankton in Lake Geneva: A Multi-Table Approach. Journal of Plankton Research, 24, 993-1007.

http://dx.doi.org/10.1093/plankt/24.10.993 